\title{
Mesozoic high-Ba-Sr granitoids from North China: geochemical characteristics and geological implications
}

\author{
Qing Qian, ${ }^{1}$ Sun-Lin Chung, ${ }^{2}$ Tung-Yi Lee ${ }^{3}$ and Da-Jen Wen ${ }^{2}$ \\ ${ }^{1}$ Key Laboratory of Mineral Resources, Institute of Geology and Geophysics, Chinese Academy of Sciences, Beijing, People's Republic of \\ China; ${ }^{2}$ Department of Geosciences, National Taiwan University, 245 Choushan Road, Taipei, People's Republic of China; ${ }^{3}$ Department of \\ Earth Sciences, National Taiwan Normal University, Taipei, People's Republic of China
}

\begin{abstract}
Mesozoic magmatism occurred extensively in the North China block (NCB) and the Dabie-Sulu orogen (DSO) post-dating the North-South China collision, resulting in abundant intrusive and volcanic rocks ranging from basic to acidic compositions. The intermediate-acidic intrusive rocks can be grouped into two types, namely high-Ba-Sr granitoids and low-Ba-Sr granitoids that both have distinct geochemical characteristics. The high$\mathrm{Ba}-\mathrm{Sr}$ granitoids are similar in most of the incompatible trace element systematics to the associated basic rocks, which probably originated from melting of subcontinental lithospheric
\end{abstract}

mantle, indicating significant mantle contributions to them. Geochemical similarities are observed between the basic rocks from the NCB and DSO, implying a regional-scale magmagenerating mechanism and that mantle enrichment beneath the DSO was independent from the Triassic deep continental subduction in the region. We therefore interpret that the Mesozoic magmatism resulted from delamination of the ancient lithospheric mantle beneath the eastern part of North China.

Terra Nova, 15, 272-278, 2003

\section{Introduction}

Granitic rocks have been classified into different types by various criteria, including field geology, major and trace element geochemistry, mineralogy, assumed origin and tectonic environment (Frost et al., 2001, and references therein). Among these types, three are particularly abundant, namely the I-type, S-type (Chappell and White, 1974) and A-type (White, 1979). Generally, the traditional I-, Sand A-type granites possess low Ba and $\mathrm{Sr}$ concentrations (hence, denominated together as low-Ba-Sr granitoids). However, Tarney and Jones (1994) identified an additional type that, named high-Ba-Sr granitoids, exhibits many trace-element characteristics distinct from the low- $\mathrm{Ba}-\mathrm{Sr}$ granitoids. The high- $\mathrm{Ba}-\mathrm{Sr}$ granitoids are marked by high $\mathrm{Ba}$ and $\mathrm{Sr}$, low $\mathrm{Y}$ and heavy rare earth elements (HREE), lack of apparent negative $\mathrm{Eu}$ anomaly and depletion of $\mathrm{Nb}$ in spidergrams.

The North China block (NCB), underlain by the Sino-Korean craton, was relatively stable from the Mesoproterozoic to Late Palaeozoic. It was

Correspondence: Dr Qing Qian, Institute of Geology and Geophysics, Chinese Academy of Sciences, PO Box 9825, Beijing 100029, China. Tel.: $86 \quad 10 \quad 62007825$; fax: 8610 62010846; e-mail: qianqing@ mail.igcas.ac.cn amalgamated with the Siberian block to the north in the Late Palaeozoic along the central Asian orogenic belt (Sengör et al., 1993), and collided with the South China block (SCB) to the south during the Triassic (Li et al., 2000) along the Qinling-Dabie-Sulu orogenic belt. The latter resulted in deep ( $>200 \mathrm{~km}$ ) subduction of the SCB beneath the NCB along the Dabie-Sulu orogen (DSO) (Ye et al., 2000). Following the continental collision, a series of geological events (the Yanshanian movements) occurred in the eastern part of North China, of which the most prominent are: (1) replacement of a cold, thick $(>180 \mathrm{~km})$ and refractory lithospheric keel (Archaean in age, Gao et al., 2002) beneath the NCB by relatively hot, thin $(\sim 80 \mathrm{~km})$ and fertile mantle (Griffin et al., 1998; Menzies and Xu, 1998; Fan et al., 2000); and (2) widespread occurrence of magmatism (mainly 165-100 Ma in age) in the eastern part of the NCB and the DSO (Fig. 1) (Wang et al., 1996; Chen et al., 1997; Ma et al., 1998; Fan et al., 2001). Replacement of the lithospheric mantle probably occurred from Jurassic to Late Cretaceous (Xu, 2001), largely contemporaneous with the magmatism. Hence the Yanshanian magmatism may be an important manifestation of mantle evolution beneath the NCB.

However, there is still controversy about the geochemistry and petrogen- esis of the Yanshanian igneous rocks. Wang et al. (1996) proposed that these rocks are dominantly shoshonitic and subordinately high-K calcalkaline in character, forming a 'shoshonite province', while $\mathrm{Xu}$ et al. (1999) argued that they are mainly high-K calc-alkaline and subordinately alkaline, with minor shoshonitic series. Zhang et al. (2001a,b) interpreted most of them as adakites derived by high-pressure melting of lower continental crust (garnet-in and plagioclase-out). Based on a compilation of 192 analyses from the literature (Appendix), plotted in Figs 2-4, we show that the intermediate to acidic rocks from the NCB and DSO comprise dominantly high-Ba-Sr granitoids and subordinately low$\mathrm{Ba}-\mathrm{Sr}$ granitoids. This identification leads to some geological implications that markedly differ from the previous views.

\section{Geochemical characteristics of the Yanshanian magmatism}

The Yanshanian igneous rocks from the NCB and DSO show a wide range of composition, with $\mathrm{SiO}_{2}$ varying continuously from $\sim 46.5-77.5 \mathrm{wt} \%$ (Fig. 2a). In the $\mathrm{SiO}_{2}$ vs. $\mathrm{K}_{2} \mathrm{O}$ diagram (Fig. 2b), the rocks plot dominantly in high-K calc-alkaline field, and subordinately in shoshonitic and rarely in medium-K calc-alkaline fields, showing an overall potassic character. 


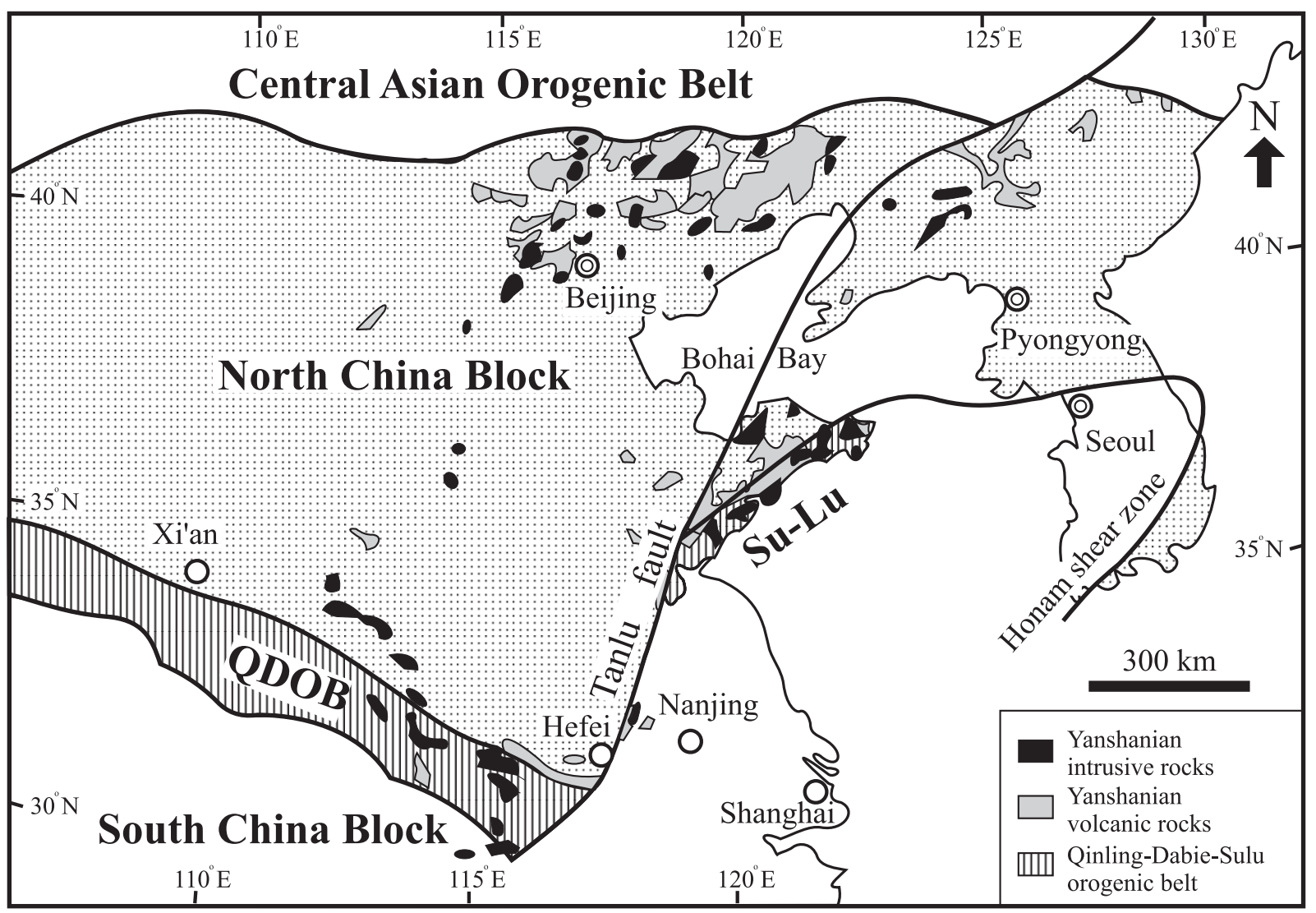

Fig. 1 Sketch map of the distribution of the Yanshanian igneous rocks from North China and the Dabie-Sulu orogenic belt (modified after Chung, 1999).
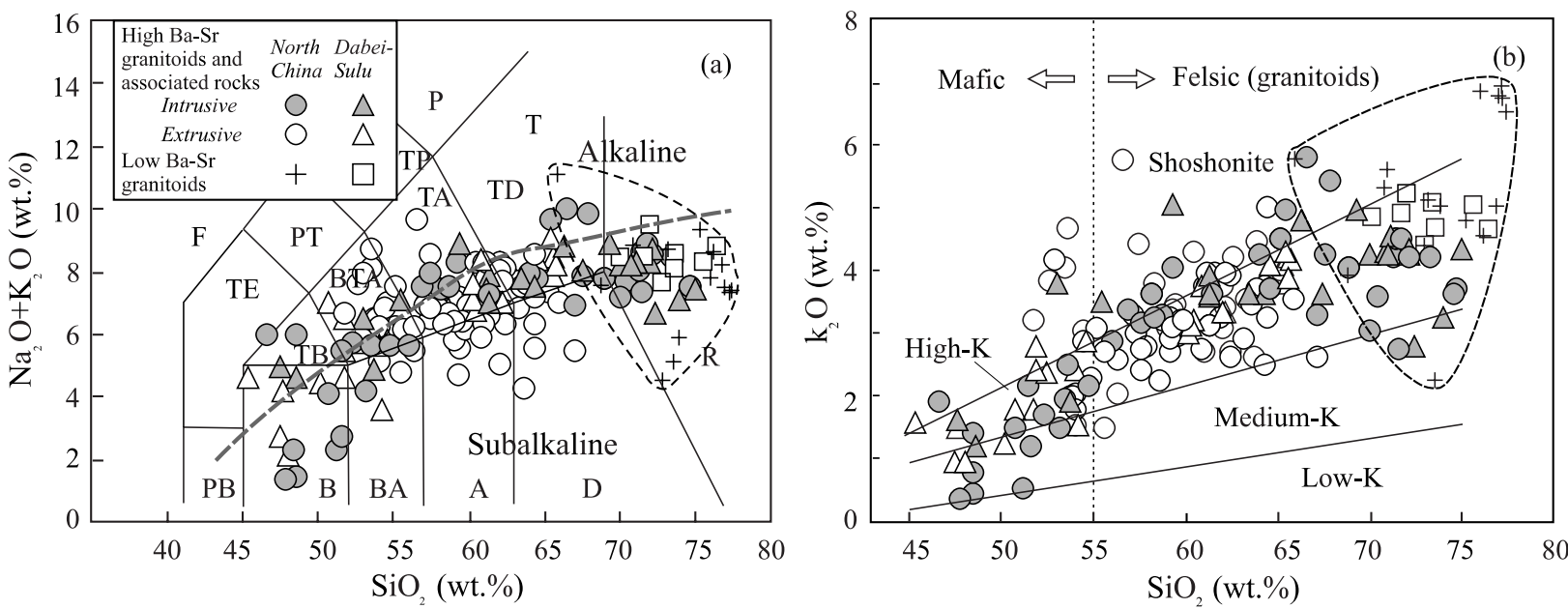

Fig. 2 Geochemical classification diagrams for Mesozoic igneous rocks from the North China Block (NCB) and Dabie-Sulu orogen (DSO). (a) $\mathrm{Na}_{2} \mathrm{O}+\mathrm{K}_{2} \mathrm{O}$ vs. $\mathrm{SiO}_{2}$ diagram. Key to abbreviations: PB, picrobasalt; B, basalt; $\mathrm{BA}$, basaltic andesite; A, andesite; D, dacite; R, rhyolite; TB, trachybasalt; BTA, basaltic trachyandesite; TA, trachyandesite; TD, trachydacite; T, trachyte; TE, tephrite; PT, phonotephrite; TP, tephriphonolite; P, phonolite; F, foidite. (b) $\mathrm{K}_{2} \mathrm{O}$ vs. $\mathrm{SiO}_{2}$ diagram. Note that rocks with $\mathrm{SiO}_{2}$ $<55 \mathrm{wt} \%$ and $>55 \mathrm{wt} \%$ are classified as mafic and felsic (granitoids if intrusive), respectively. Dashed line delineates the areas of the low-Ba-Sr granitoids. Data from the NCB are from Qin (1995), Chen et al. (1997), Xu et al. (1999), Qiu et al. (2000) and Guo et al. (2001). Data from the DSO are from Ma et al. (1998), Jahn et al. (1999) and Fan et al. (2001). 

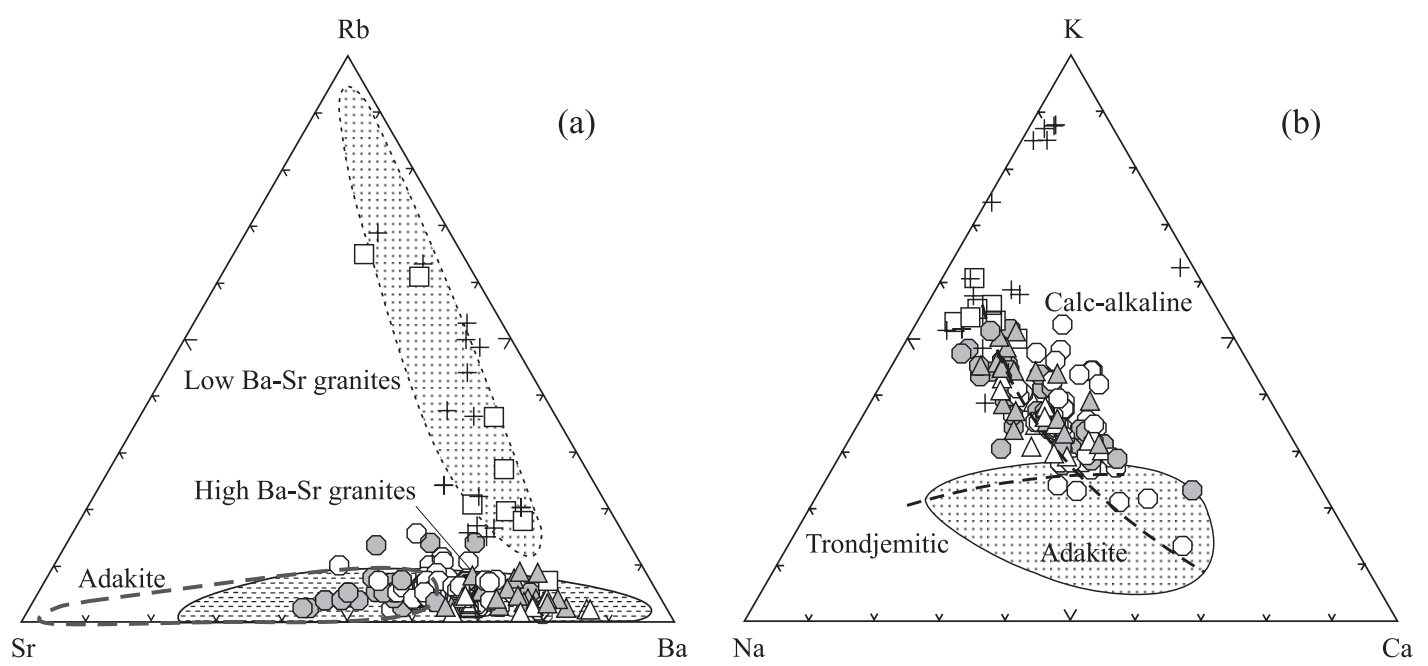

Fig. 3 (a) Sr-Rb-Ba plot (after Tarney and Jones, 1994), and (b) Na-K-Ca plot for Yanshanian intermediate-acidic rocks from the North China Block (NCB) and Dabie-Sulu orogen (DSO). Sample symbols are the same as that in Fig. 2. Fields of high-Ba-Sr and low-Ba-Sr granitoids are based on data from Fowler and Henney (1996) and Fowler et al. (2001). Fields of adakite are based on data from Kay (1978), Defant et al. (1991a,b), Sajona et al. (1993, 1994), Morris (1995), Stern and Kilian (1996) and Yogodzinski et al. $(1994,1995)$.

Rocks with $\mathrm{SiO}_{2}>55 \mathrm{wt} \%$ and $<55 \mathrm{wt} \%$ are termed felsic and mafic, respectively.

Based on $\mathrm{Sr}$ and $\mathrm{Ba}$ abundances, the granitoids can be divided into two types, namely, the high-Ba-Sr granitoids and low-Ba-Sr granitoids. The former generally have $\mathrm{Sr}>$ 300 p.p.m. and $\mathrm{Ba}>500$ p.p.m., and the latter have $\mathrm{Sr}<300$ p.p.m. and $\mathrm{Ba}<500$ p.p.m. This criterion applies well for most of the samples, except a few samples with low $\mathrm{Sr}$ (< 300 p.p.m.) but high Ba (up to 1470 p.p.m.) concentrations (grouped as low-Ba-Sr granitoids). In Tarney and Jones' (1994) Sr-Rb-Ba plot (Fig. 3a), the two types show apparently different trends, similar to the Scottish Caledonian granitoids. In addition, the high-Ba-Sr granitoids have high light rare earth elements (LREEs), low Y (4-30 p.p.m.) and heavy rare earth elements (HREEs), and depleted $\mathrm{Nb}$ (but not $\mathrm{Eu}$ ) in spidergrams (Fig. 4a,b). Consequently, they have high $\mathrm{Sr} / \mathrm{Y}$ (16170) (Fig. 4d) and $\mathrm{La} / \mathrm{Yb}(10-115)$ ratios. The low-Ba-Sr granitoids are also depleted in $\mathrm{Nb}$, but in contrast strongly depleted in $\mathrm{Ba}, \mathrm{Sr}$ and $\mathrm{Eu}$ (Fig. 4a,b) and have lower $\mathrm{Sr} / \mathrm{Y}(1.8-$ 21) (Fig. 4d) and $\mathrm{La} / \mathrm{Yb}(6-56)$ ratios. It is notable that the high-Ba-Sr granitoids have incompatible element patterns similar to that of the associated mafic rocks (which is also true of many orogenic rocks worldwide, Tarney and Jones, 1994), but are relatively lower in most of the moderate to slight incompatible elements (Fig. 4a,b).

The two types of granitoids also show differences in major element compositions. The high- $\mathrm{Ba}-\mathrm{Sr}$ granitoids have a relatively more mafic member and thus wider range of $\mathrm{SiO}_{2}(55.5-74.8 \mathrm{wt} \%)$, coupled with higher $\mathrm{Al}_{2} \mathrm{O}_{3}(11.5-18.4 \mathrm{wt} \%$, mostly $>14.0 \mathrm{wt} \%)$ and $\mathrm{P}_{2} \mathrm{O}_{5} \quad(0.02-0.89$ $\mathrm{wt} \%$, mostly $>0.20 \mathrm{wt} \%$ ) contents, and lower $\mathrm{K}_{2} \mathrm{O} / \mathrm{Na}_{2} \mathrm{O}$ (0.6-1.6). Corresponding values for the low-Ba-Sr granitoids are: $66.0-77.5 \mathrm{wt} \%, 11.5$ $16.8 \mathrm{wt} \% \quad($ mostly $<14.0 \mathrm{wt} \%)$, $0.02-0.25 \mathrm{wt} \%$ (mostly $<0.20 \mathrm{wt} \%$ ) and $0.8-9.4$, respectively.

The high-Ba- $\mathrm{Sr}$ granitoids from the NCB have a wide range in $\varepsilon \mathrm{Nd}(\mathrm{T})$ (T) $(-3.8$ to -20.2$)$ but have a restricted range of initial ${ }^{87} \mathrm{Sr} /{ }^{86} \mathrm{Sr}$ ratios $(0.7051-0.7068)$. Those from the DSO are more uniform in $\varepsilon \mathrm{Nd}(\mathrm{T})$ $(-15.2$ to -21.4$)$, with relatively higher initial ${ }^{87} \mathrm{Sr} /{ }^{86} \mathrm{Sr}$ ratios $(0.7058$ 0.7096). Moreover, isotope compositions of the high-Ba-Sr granitoids are largely identical with those of the associated mafic rocks in each region (Fig. 4c). Nd-depleted mantle model ages $\left(T_{\mathrm{DM}}\right)$ of the high-Ba-Sr granitoids and mafic rocks mostly range between 1.50 and $2.20 \mathrm{Ga}$ in both regions (Appendix). Limited $\mathrm{Sr}-\mathrm{Nd}$ isotope data available for the low$\mathrm{Ba}-\mathrm{Sr}$ granitoids are heterogeneous, with initial ${ }^{87} \mathrm{Sr} /{ }^{86} \mathrm{Sr}$ and $\varepsilon \mathrm{Nd}(\mathrm{T})$ values of $0.7043-0.7317$ and -9.4 to - 13.0, and 0.7086-0.7149 and - 14.0 to -20.5 for samples from the $\mathrm{NCB}$ and DSO, respectively (Appendix).

\section{Magma source and petrogenesis of high-Ba-Sr granitoids}

Two competing hypotheses have been proposed for the genesis of high-Ba-Sr granitoids. One is by Tarney and Jones (1994) who explored partial melting of three possible precursor magma sources: (1) subducted ocean islands or plateaus, (2) hydrous mafic underplates in the lower crust and (3) the lower continental lithosphere enriched by carbonatitic melts. The other is by Fowler and Henney (1996) and Fowler et al. (2001) who advocated the Scottish Caledonian granitoids as products of crystal fractionation from associated shoshonitic mafic magmas that originated from an enriched mantle lithosphere. In the latter, it is considered that crystallization of highly REE-conserved accessory minerals such as apatite and titanite play a crucial role in decreasing the abundances of REE, $\mathrm{P}$ and $\mathrm{Ti}$ through differentiation.

In North China, the Badaling complex (located $\sim 40 \mathrm{~km}$ north of 

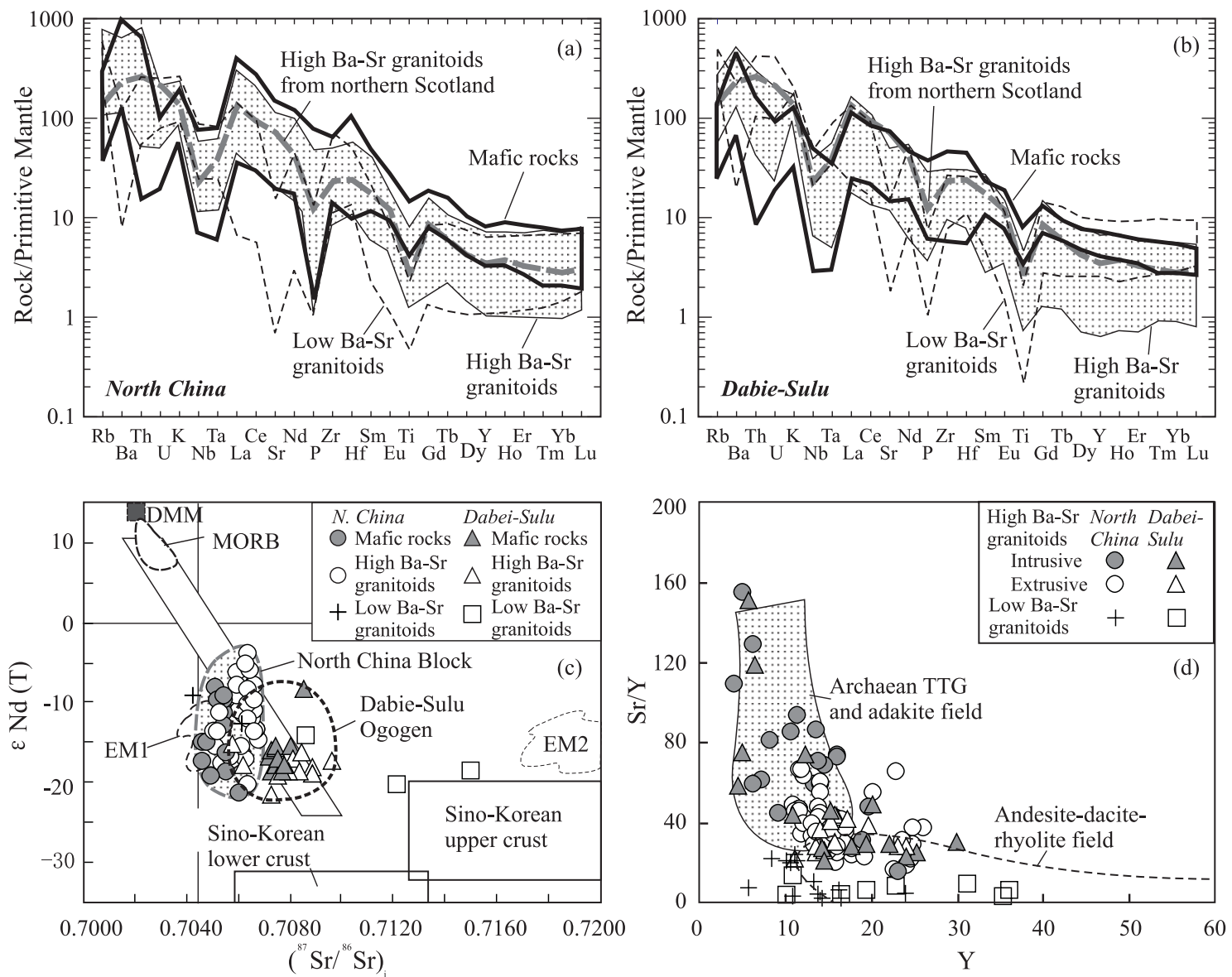

Fig. 4 (a,b) Primitive mantle-normalized multi-element distribution diagrams for Yanshanian igneous rocks from the North China Block (NCB) and Dabie-Sulu orogen (DSO), respectively. Normalizing data are after Sun and McDonough (1989). High-Ba-Sr granitoids from the Scottish Caledonian Orogen (Fowler et al., 2001) are shown for comparison. (c) Initial ${ }^{87} \mathrm{Sr} /{ }^{86} \mathrm{Sr} v s . \varepsilon N d(\mathrm{~T})$ plot. Fields of Sino-Korean lower and upper crust are after Jahn et al. (1999). (d) Y vs. Sr/Y plot for Yanshanian igneous rocks from the NCB and DSO. Fields of Archaean TTG (trondhjemite, tonalite and granodiorite) and adakites, and arc andesite-daciterhyolite are after Martin (1999).

Beijing) serves as a good case example that comprises a whole series of magmas from mafic to intermediate and acidic compositions to study the magma source and petrogenesis of high-Ba-Sr granitoids. Major and trace element and $\mathrm{Sr}-\mathrm{Nd}$ isotope data of the mafic rocks and high$\mathrm{Ba}-\mathrm{Sr}$ granitoids suggest that the Badaling high-Ba-Sr granitoids were generated by differentiation of the associated mafic magmas derived from an enriched subcontinental lithospheric mantle, with substantial crustal contamination (Qian et al., 2002). Similarly, Li et al. (2002) postulated that Jurassic basaltic rocks from western Liaoning in the NCB originated from an enriched lithospheric mantle, and the accompanied andesitic and dacitic rocks (also high in $\mathrm{Ba}$ and $\mathrm{Sr}$ ) represent differentiated products from the basaltic magmas through a combined assimilation and fractional crystallization (AFC) process. Ma et al. (1998) proposed a similar interpretation for coeval mafic rocks and high $\mathrm{Ba}-\mathrm{Sr}$ granitoids (mainly Group II of Ma et al.'s classification) from the northern Dabie Mountains. Given the fact that high-Ba-Sr granitoids from both the NCB and the DSO exhibit incompatible elemental characteristics and $\mathrm{Sr}-\mathrm{Nd}$ isotope compositions almost indistinguishable from those of the associated mafic rocks (Fig. $4 a-c)$, we argue that the high- $\mathrm{Ba}-\mathrm{Sr}$ granitoids contain a significant mantle component. Similarities in the multi-element distribution patterns between the high-Ba-Sr granitoids and the associated mafic rocks have been observed in Scottish Caledonides and many other orogens worldwide (Tarney and Jones, 1994), interpreted to indicate large mantle contributions to the generation of high-Ba-Sr granitoids (Tarney and Jones, 1994; Fowler et al., 2001). Enrichment of the lithospheric mantle beneath the NCB may have been caused by interactions with small-volume melts from the lithosphere, asthenosphere or recycled crustal materials (Menzies, 1990). A similarly enriched old mantle lithosphere may also exist beneath the DSO (Fan et al., 2001). In contrast, the low-Ba-Sr granitoids were possibly derived from melting of the lower-middle continental crust (Qian et al., 2002). 


\section{Geological implications}

Tarney and Jones (1994) pointed out that high-Ba-Sr granitoids dominate in the Archaean, and also occur extensively as plutons and volcanics in many Late Cretaceous and Tertiary orogenic belts worldwide. Our observations from North China lead to identification of an important high$\mathrm{Ba}-\mathrm{Sr}$ granitoid province of Mesozoic age. The high-Ba-Sr granitoids and their extrusive associates from the NCB and DSO show elemental characteristics (e.g. high Sr, Ba and LREE, low $\mathrm{Y}$ and HREE, elevated $\mathrm{La} / \mathrm{Yb}$ and $\mathrm{Sr} / \mathrm{Y}$ ratios, and lack of negative $\mathrm{Eu}$ anomaly) that are typical of adakites and Archaean TTG (trondhjemite, tonalite and granodiorite) suites (Martin, 1986; Drummond and Defant, 1990; Martin, 1999, and references therein). Therefore, they have been envisaged by some workers as adakites derived from lower crustal melting under high pressure with eclogite residue (Zhang et al., 2001a,b; Defant et al., 2002). Zhang et al. (2001a) further argued that the continental crust of the NCB was $>50 \mathrm{~km}$ thick during the Mesozoic so that there was an 'East China Plateau' comparable in height to the present Tibet. However, we note that these high-Ba-Sr granitoids are different from adakites by possessing higher $\mathrm{K}_{2} \mathrm{O} / \mathrm{Na}_{2} \mathrm{O}$ (0.65-1.1), more variable $\mathrm{Al}_{2} \mathrm{O}_{3} \quad(11.5-19.5 \mathrm{wt} \%)$ and much more enriched $\mathrm{Sr}$ and $\mathrm{Nd}$ isotopes. Furthermore, they delineate a calcalkaline trend, rather than showing the trondhjemitic affinities of adakites in the $\mathrm{Na}-\mathrm{K}-\mathrm{Ca}$ plot (Fig. 3b), and are associated with $\mathrm{Nb}$-depleted potassic mafic rocks (Ma et al., 1998; Chen et al., 2002; Li et al., 2002; Qian et al., 2002), in contrast to adakites that are occasionally associated with $\mathrm{Nb}$-enriched basalts (Aguillón-Robles et al., 2001, and references therein). The adakite-like geochemical features of the high-Ba-Sr granitoids can be explained as reflecting the enriched mantle source signatures, followed by differentiation of highly REEconserved accessory phases ( $\mathrm{Li}$ et al., 2002; Qian et al., 2002), similar to the case reported in the Scottish Caledonides (Fowler and Henney, 1996; Fowler et al., 2001). Hence we argue that the adakite-like elemental characteristics of the high-Ba-Sr granitoids do not witness high-pressure melting of the lower crust.

Post-collisional interactions of the subducted crust (i.e. part of the SCB) with the asthenosphere (Jahn et al., 1999) or the North China mantle lithosphere (Li et al., 1998; Fan et al., 2001) have been envisaged to explain some of the arc-type geochemical characteristics (e.g. enriched LILE, depleted $\mathrm{Nb}$, and enriched $\mathrm{Sr}$ and $\mathrm{Nd}$ isotopes) of the mafic rocks from the DSO. These scenarios, however, could not apply further northward to account for the widespread occurrence of contemporaneous magmatism with similar elemental and isotopic characteristics (Fig. 4a-c) in the northern part of the NCB (Fig. 1). Taking the occurrence of Ordovician kimberlites into account, the suggested presence of an ancient (Griffin et al., 1998; O'Reilly et al., 2001) and enriched $(\mathrm{Xu}, 2001)$ mantle source in the NCB is considered vital, and consistent with the Nd $T_{\text {DM }}$ data (Appendix) dominated by Palaeo- to Meso-proterozoic ages. Such a tempero-spatial association and petrochemical similarities of the Yanshanian magmas from the NCB and DSO indicate that mantle source enrichment beneath the DSO does not require continental subduction, but does require a larger-scale mechanism for the magma generation in the regions.

Basalt- and kimberlite-borne mantle xenoliths and geophysical data have consistently documented that delamination of c. $80-140 \mathrm{~km}$ of Archaean lithospheric mantle took place beneath the NCB during the Mesozoic (Griffin et al., 1998; Menzies and $\mathrm{Xu}, 1998$; $\mathrm{Xu}, 2001)$, coeval with the Yanshanian magmatism. The identification of the high-Ba-Sr granitoids provides further information that links the magmatism and the mantle evolution. Considering the significant contribution of the lithospheric mantle to the high-Ba-Sr granitoids and making reference to other continental collision zones where removal of the lower part of thickened lithospheric mantle has been widely accepted for causing post-collisional magmatism (Platt and England, 1994), we invoke delamination of the ancient Sino-Korean cratonic mantle lithosphere and upward movement of hotter asthenosphere to account for the post-collisional magmatism in the NCB and DSO. The geotherm thus raised may have triggered partial melting of veined peridotite (Foley, 1992) within the remnant lithospheric mantle to form potassic mafic magmas, some of which later differentiated into the high-Ba-Sr granitoids. The resultant extension and basin formation lasted into the Cenozoic and, after a substantial amount of lithospheric thinning was achieved, led to a new episode of magmatism consisting exclusively of intraplate basalts (Chung, 1999) resulting from decompression melting of the ascended asthenosphere. Furthermore, detailed studies, in particular precise dating of the Yanshanian magmatism, are required to unravel the complete scenario of tectonic evolution from stable craton to extension in North China.

\section{Concluding remarks}

The geochemical data presented here suggest that in the NCB and DSO the intermediate-acidic rocks of the Yanshanian post-collisional magmatism consist dominantly of high-Ba-Sr granitoids and subordinately of low$\mathrm{Ba}-\mathrm{Sr}$ granitoids. The geochemical and $\mathrm{Sr}-\mathrm{Nd}$ isotope characteristics of the high-Ba- $\mathrm{Sr}$ granitoids are similar to those of the associated mafic lavas, suggesting significant contributions from the enriched lithospheric mantle to this type of granitoid. Geochemical similarities of the Yanshanian magmatism from the $\mathrm{NCB}$ and DSO require a regional-scale magma-generating mechanism that we ascribe to delamination of the Sino-Korean cratonic lithospheric mantle.

\section{Supplementary material}

The following supplementary material is available from http://www.black wellpublishing.com/products/journals/ suppmat/ter/ter491/ter491sm.htm

\section{Appendix}

Compiled data of Yanshanian igneous rocks from the North China Block (NCB) and Dabie-Sulu Orogen (DSO).

\section{Acknowledgments}

Comments from two anonymous reviewers that led to significant improvement of this paper are highly appreciated. This 
study has been supported by Major State Basic Research Development Program (G1999075502) and National Natural Science Foundation (No. 40002006) of China.

\section{References}

Aguillón-Robles, A., Caimus, T., Benort, M., Bellon, H., Maury, R.C., Cotton, J., Bourgois, J. and Michaud, F., 2001. Late Miocene adakites and $\mathrm{Nb}$-enriched basalts from Vizcaino Peninsula, Mexico: indicators of East Pacific Rise subduction below southern Baja California? Geology, 29, 531-534.

Chappell, B.W. and White, A.J.R., 1974. Two contrasting granite types. Pacific Geol., 8, 173-174.

Chen, Y.X., Chen, W.J. and Zhou, X.H., 1997. Geochronology, Geochemistry and Tectonic Settings of Mesozoic Volcanic Rocks in Western Liaoning and Its Adjacent Regions. Seismologic Press, Beijing (in Chinese with English abstract).

Chen, B., Jahn, B.M. and Wei, C.J., 2002. Petrogenesis of Mesozoic granitoids in the Dabie UHP complex, Central China: trace element and $\mathrm{Nd}-\mathrm{Sr}$ isotope evidence. Lithos, 60, 67-88.

Chung, S.L., 1999. Trace element and isotope characteristics of Cenozoic basalts around the Tanlu Fault with implications for the Eastern Plate Boundary between North and South China. J. Geol., 107, 301-312.

Defant, M.J., Clark, L.F., Stewart, R.H., Drummond, M.S., De Boer, J.Z., Maury, R.C., Bellon, H., Jackson, T.E. and Restrepo, J.F., 1991a. Andesite and dacite genesis via contrasting processes: the geology and geochemistry of EI Valle Volcano, Panama. Contrib. Miner. Petrol., 106, 309-324.

Defant, M.J., Richerson, P.M., De Boer, J.Z., Stewart, R.H., Maury, R.C., Bellon, H., Drummond, M.S., Feigenson, M.D. and Jackson, T.E., 1991b. Dacite genesis via both slab melting and differentiation: petrogenesis of $\mathrm{La}$ Yeguada volcanic complex, Panama. J. Petrol., 32, 1101-1142.

Defant, M.J., Xu, J.F., Kepezhinskas, P., Wang, Q., Zhang, Q. and Xiao, L., 2002. Adakites: some variations on a theme. Acta Petrol. Sinica, 18, 129-142.

Drummond, M.S. and Defant, M.J., 1990. A model for trondhjemite-tonalite-dacite genesis and crustal growth via slab melting: Archean to modern comparisons. J. Geophys. Res., 95, 21503-21521.

Fan, W.M., Guo, F., Wang, Y.J., Lin, G. and Zhang, M., 2001. Post-orogenic bimodal volcanism along the Sulu Orogenic Belt in eastern China. Phys. Chem. Earth (a), 26, 733-746.
Fan, W.M., Zhang, H.F., Baker, J., Jarvis, K.E., Mason, P.R.D. and Menzies, M.A., 2000. On and off the North China craton: where is the Archaean keel? J. Petrol., 41, 933-950.

Foley, S., 1992. Vein-plus-wall-rock melting mechanisms in the lithosphere and the origin of potassic alkaline magmas. Lithos, 28, 435-453.

Fowler, M.B. and Henney, P.J., 1996. Mixed Caledonian appinite magmas: implications for lamprophyre fractionation and high $\mathrm{Ba}-\mathrm{Sr}$ granite genesis. Contrib. Miner. Petrol., 126, 199-215.

Fowler, M.B., Henney, P.J., Darbyshire, D.P.F. and Greenwood, P.B., 2001. Petrogenesis of high Ba-Sr granites: the Rogart pluton, Sutherland. J. Geol. Soc. London, 158, 521-534.

Frost, B.R., Barnes, C.G., Collins, W.J., Arculus, R.J., Ellis, D.J. and Frost, C.D., 2001. A geochemical classification for granitic rocks. J. Petrol., 42, 20332048.

Gao, S., Rudnick, R.L., Carlson, R.W., McDonough, W.F. and Liu, Y.S., 2002. $\mathrm{Re}-\mathrm{Os}$ evidence for replacement of ancient mantle lithosphere beneath the North China Craton. Earth Planet. Sci. Lett., 198, 307-322.

Griffin, W.L., Zhang, A.D., O'Reilly, S.Y. and Ryan, C.G., 1998. Phanerozoic evolution of the lithosphere beneath the Sino-Korean Craton. In: Mantle Dynamics and Plate Interactions in East Asia (M. F. J. Flower, S. L. Chung, C. H. Lo and T. Y. Lee, eds), pp. 107126. American Geophysical Union Geodynamics Series 27. American Geophysical Union, Washington.

Guo, F., Fan, W.M., Wang, Y.J. and Lin, G., 2001. Late Mesozoic mafic intrusive complexes in North China Block: constraints on the nature of subcontinental lithospheric mantle. Phys. Chem. Earth (a), 26, 759-771.

Jahn, B.M., Wu, F.Y., Lo, C.H. and Tsai, C.H., 1999. Crust-mantle interaction induced by deep subduction of the continental crust: geochemical and $\mathrm{Sr}-\mathrm{Nd}$ isotopic evidence from post-collisional mafic-ultramafic intrusions of the northern Dabie complex, central China. Chem. Geol., 157, 119-146.

Kay, R.W., 1978. Aleutian magnesian andesites: melts from subduction Pacific ocean crust. J. Vol. Geotherm. Res., 4, 117-132.

Li, S., Jagoutz, E., Chen, Y.Z. and Li, Q.L., 2000. Sm-Nd and $\mathrm{Rb}-\mathrm{Sr}$ isotopic chronology and cooling history of ultrahigh pressure metamorphic rocks and their country rocks at Shuanghe in the Dabie Mountains, Central China. Geochim. Cosmochim. Acta, 64, $1077-$ 1093.

Li, W.P., Li, X.H., Lu, F.X., Zhou, Y.Q. and Zhang, D.G., 2002. Geological characteristics and its setting for volcanic rocks of early Cretaceous Yixian Formation in western Liaoning province, eastern China. Acta Petrol. Sinica, 18, 193-204 (in Chinese with English abstract).

Li, S., Nie, Y.H., Hart, S.R. and Zheng. S.G., 1998. Upper mantle-deep subducted continental crust interaction: (II) $\mathrm{Sr}$ and $\mathrm{Nd}$ isotopic constraints on the syn-collisional mafic to ultramafic intrusions in the northern Dabieshan, eastern China. Science in China (Series D), 28, $18-22$.

Ma, C., Li, Z., Ehlers, C., Yang, K. and Wang, R., 1998. A post-collisional magmatic plumbing system: Mesozoic granitoid plutons from the Dabieshan high-pressure and ultrahigh-pressure metamorphic zone, east-central China. Lithos, 45, 431-456.

Martin, H., 1986. Effect of steeper Archean geothermal gradient on geochemistry of subduction-zone magmas. Geology, 14, 753-756.

Martin, H., 1999. Adakite magmas: modern analogues of Archean granitoids. Lithos, 46, 411-429.

Menzies, M.A., 1990. Archaean, Proterozoic, and Phanerozoic lithospheres. In: Continental Mantle (M. A. Menzies, ed.), pp. 67-86. Clarendon Press, Oxford.

Menzies, M.A. and Xu, Y.G., 1998. Geodynamics of the North China craton. In: Mantle Dynamics and Plate Interactions in East Asia (M. F. J. Flower, S. L. Chung, C. H. Lo and T. Y. Lee, eds), pp. 155-165. American Geophysical Union Geodynamics Series 27. American Geophysical Union.

Morris, P.A., 1995. Slab melting as an explanation of Quaternary volcanism and aseismicity in southwest Japan. Geology, 23, 395-398.

O'Reilly, S.Y., Griffin, W.L., Djomani, Y.H.P. and Morgan, P., 2001. Are lithospheres forever? Tracking changes in subcontinental lithospheric mantle through time. GSA Today, 11, 4-9.

Platt, J.P. and England, P.C., 1994. Convective removal of lithosphere beneath mountain belts: thermal and mechanical consequences. Am. J. Sci., 294, 307-336.

Qian, Q., Chung, S.L., Lee, T.Y. and Wen, D.J., 2002. Geochemical characteristics and petrogenesis of the Badaling high $\mathrm{Ba}-\mathrm{Sr}$ granitoids: a comparison of igneous rocks from North China and the Dabie-Sulu Orogen. Acta Petrol. Sinica, 18, 275-292 (in Chinese with English Abstract).

Qin, D.J., 1995. Yanshanian magma activity and mineralization in Lingqiu-Laiyuan Area. Doctoral Dissertation, Beijing University (in Chinese with English abstract).

Qiu, J.S., Lo, C.H., McInnes, B.I.A. and Zhou, J.C., 2000. Potash-rich 
magmatism and associated gold-copper mineralization in the Yishu deep fault zone and its vicinity, eastern China. Resource Geol., 50, 269-280.

Sajona, F.G., Bellon, H., Maury, R.C., Pubellier, M., Cotton, J. and Rangin, C., 1994. Magmatic response to abrupt changes in geodynamic settings: Pliocene-Quaternary calc-alkaline and $\mathrm{Nb}$-enriched lavas from Mindanao (Philippines). Tectonophysics, 237, 47-72.

Sajona, F.G., Maury, R.C., Bellon, H., Cotton, J., Defant, M.J. and Pubellier, M., 1993. Initiation of subduction and the generation of slab melts in western and eastern Mindano, Philippines. Geology, 21, 1007-1010.

Sengör, A.M., Natal'In, B.A. and Burtman, V.S., 1993. Evolution of the Altaid tectonic collage and Palaeozoic crustal growth in Eurasia. Nature, 364, 299-307. Stern, C.R. and Kilian, R., 1996. Role of the subducted slab, mantle wedge and continental crust in the generation of adakites from the Andean Austral Volcanic Zone. Contrib. Mineral. Petrol., 123, 263-281.

Sun, S.-S. and McDonough, W.F., 1989. Chemical and isotopic systematics of oceanic basalts: implications for mantle composition and processes. In: Magma- tism in the Ocean Basins (A. D. Saunders and M. J. Norry, eds). Geol. Soc. [London] Spec. Publ., 42, 313-345.

Tarney, J. and Jones, C.E., 1994. Trace element geochemistry of orogenic igneous rocks and crustal growth models. J. Geol. Soc. London, 151, 855-868.

Wang, D.Z., Ren, Q.J., Qiu, J.S., Chen, K.R., Xu, Z.W. and Zen, J.H., 1996. Characteristics of volcanic rocks in the shoshonite province, eastern China, and their metallogenesis. Acta Geol. Sinica, 70, 23-34 (in Chinese with English Abstract).

White, A.J.R., 1979. Sources of granite magmas. Geol. Soc. Am., Abstracts with Programs, 11, 539.

$\mathrm{Xu}$, Y.G., 2001. Thermo-tectonic destruction of the Archaean lithospheric keel beneath the Sino-Korean craton in China: evidence, timing and mechanism. Phys. Chem. Earth (a), 26, 747-757.

Xu, B.L., Yan, G.H. and Xu, Z.B., 1999. Geochemistry and genetic implication of three series of Yanshanian granite in northern Hebei Province. Acta Petrol. Sinica, 15, 208-216 (in Chinese with English abstract).

Ye, K., Cong, B.L. and Ye, D.N., 2000. The possible subduction of continental material to depths greater than $200 \mathrm{~km}$. Nature, 407, 734-736.
Yogodzinski, G.M., Kay, R.W., Bolynets, O.N., Koloskov, A.V. and Kay, S.M., 1995. Magnesian andesite in the western Aleutian Komandorsky region: implications for slab melting and processes in the mantle wedge. Geol. Soc. Am. Bull., 107, 505-519.

Yogodzinski, G.M., Volynets, O.N., Koloskov, A.V., Seliverstov, N.I. and Matvenkov, V.V., 1994. Magnesian andesites and the subduction component in a strongly calc-alkaline series at Piip Volcano, far western Aleutians. J. Petrol., 35, 163-204.

Zhang, Q., Qian, Q., Wang, E.Q., Wang, Y., Zhao, T.P., Hao, J. and Guo, G.J., 2001a. An East China plateau in midlate Yanshanian period: implication from adakites. Chinese J. Geol., 36, 248-255 (in Chinese with English abstract).

Zhang, Q., Wang, Y. and Wang, Y.L., 2001 b. Preliminary study on the components of the lower crust in east China Plateau during Yanshanian Period: constraints on $\mathrm{Sr}$ and $\mathrm{Nd}$ isotopic compositions of adakite-like rocks. Acta Petrol. Sinica, 17, 505-513 (in Chinese with English abstract).

Received 18 July 2002; revised version accepted 30 April 2003 